\title{
Current discussions on consumer redress: collective redress and ADR
}

\section{Christopher Hodges}

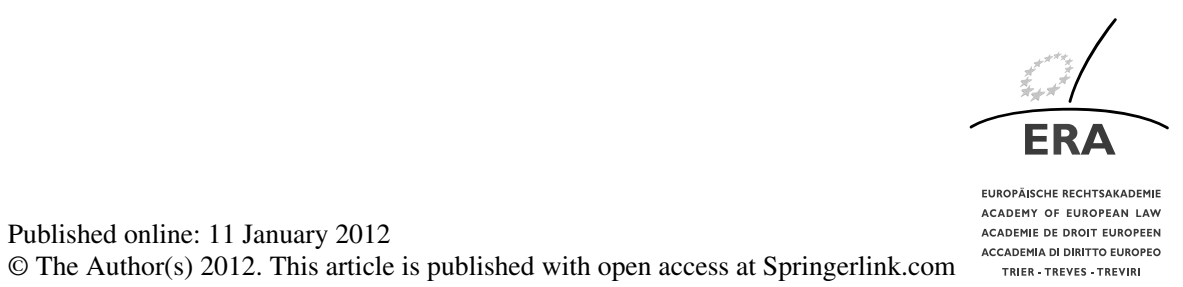

\begin{abstract}
The two topics of collective redress and ADR might, at first sight, appear to have little in common. One is usually thought to relate to a court, judicial procedure and the other to a non-judicial procedure. The first essentially involves coercion and the second its opposite, voluntary agreement. But in fact these two subjects have become closely related, both in practice and politically. This paper will start by summarising the historical development of each procedure, and the debate that surrounds each, showing how the two streams have become merged.
\end{abstract}

Keywords Consumer redress · Collective redress · Alternative dispute resolution

\section{Collective redress}

Two facts are widely known. Firstly, mass problems can occur. There can be arguments over whether bank charges are too high; whether terms and conditions are unfair commercial practice; whether a medicine has caused injuries; whether government actions are illegal. Such issues can affect many people. The interests of economy suggest that similar issues should be dealt with together, so as to achieve coherent, consistent and economical results.

Secondly, the mass technique that is most well known, is the American class action, which has been extensively used in the United States of America since the 1960s.

This article is based on a contribution given at the Annual Conference on European Consumer Law 2011 , organised by ERA on 13 October 2011 in Trier.

Professor Dr. C. Hodges $(\varangle)$, Head of the CMS Research Programme on Civil Justice Systems

Centre for Socio-Legal Studies

University of Oxford, Manor Road, Oxford OX1 3QU, UK

e-mail: christopher.hodges@csls.ox.ac.uk 
Various governments around the world have introduced rules on mass judicial procedures that are broadly based on the US class action model. Yet many European governments have been notably tentative about introducing a class action. This may have occurred politically as a result of pressure from business, but the underlying concern is about what Europeans perceive to be the 'abuse' that is associated with the US class action. ${ }^{1}$

But the debate in Europe has moved in directions that may surprise many observers. Essentially, if we ask what we are trying to achieve, and then ask what options exist for achieving the real goals, we end up with a different approach. This involves putting to one side the assumption that the courts offer the only technique that can deliver redress. It involves looking afresh at all available options. That is where ADR comes in, in a new matrix of techniques. A judicial class action on its own may be seen as an old fashioned technique.

\subsection{Distinguishing the goals and architecture of legal systems}

One very important point has to be understood about the role that class actions play in different legal systems - because the same technique plays different roles in different systems, and realising this fact has huge implications for making a selection between the available techniques.

In general, the architecture of the entire legal system in the USA, almost uniquely around the world, strongly emphasizes private enforcement [of both private rights and public norms $],{ }^{2}$ and Americans distrust enforcement by public authorities, especially federal agencies, which they regard as being captured by the Executive. ${ }^{3}$

On the other hand, European legal systems adopt both public enforcement and private enforcement, often separating them for public norms and private rights respectively. European courts do sometimes need to manage the processing of multiple claims-but far less frequently than occurs in America, since class actions are used more frequently there as regulatory enforcement mechanisms, on an opt-out model. That is why:

- Continental civil law jurisdictions do not have discovery: instead, their substantive law aligns the definition of rights and breaches so as not to require evidence in most situations.

- The loser pays rule is almost universal. ${ }^{4}$ Contingency fees (percentages of damages or recovery) are banned in almost every European jurisdiction, although success fees are widely permitted.

- 'Class actions' for damages are very new in about half of the Member States, and they are not widely used even where they exist.

\footnotetext{
${ }^{1}$ Many leading politicians have referred to 'abuse' produced by US class actions, see below: recently see Commissioner Almunia in the hearing on collective redress for competition damages at the Economic and Monetary Affairs Committee of the European Parliament in Brussels on 22 September 2011.

${ }^{2}$ An influential analysis was Kalven, Rosenfield [21], 684-687.

${ }^{3}$ See Hodges [12].

${ }^{4}$ Hodges, Vogenauer, Tulibacka [16].
} 
Further, the prevailing theory of enforcement in USA is based solely on deterrence: imposing high costs on business, ex post, to deter future conduct. In contrast, Most European agencies (apart from DG COMP) adopt an enforcement policy that is not solely based on deterrence, such as responsive regulation, risk-based enforcement, and others. It has been argued that, a deterrence theory alone is less effective and more expensive than other enforcement policies. ${ }^{5}$ For one thing, reliance solely on an ex post deterrence theory requires imposition of huge penalties, to take into account the ex post effect and the probability of detection: since ex ante control is not relied on.

If you want to encourage the use of a private action technique, you would:

a. Remove or reducing barriers to a claimant

b. Place incentives for claimants and intermediaries (lawyers) to investigate possible wrongdoing and institute litigation.

These barriers and incentives are principally economic. There are several familiar levers:

a. No cost to the claimant (intermediary supplies funding);

b. No loser pays rule;

c. In some circumstances, a one-way cost shifting rule: claimant does not pay if loses, defendant pays if loses; ${ }^{6}$

d. High damages, so as to facilitate funding by the claimant's intermediary, and provide deterrence on defendants (see below);

e. High contingency or court-approved fees for lawyers;

f. Wide rules on discovery and depositions;

g. Punitive damages, or triple damages in antitrust;

h. Jury trials;

i. Coordination of individual claims: Class actions or Multi-District Litigation rules.

Introducing each one of the above levers would facilitate increased levels of litigation, and banning each one would discourage it. There are no other magic safeguardsyou just have to play with these levers, depending on whether you want more or less litigation. Most of these levers are within the competence of Member States, not of the EU.

Many people think that all of these levers do not exist in Europe. That is wrong. There are clear trends in several Member States, for example, towards cutting legal aid and replacing it with success fees, introducing contingency fees (in UK), ${ }^{7}$ low 'cost shifting' or one-way cost shifting, ${ }^{8}$ and financing litigation by third party funders, ${ }^{9}$ several of whom already finance collective claims.

\footnotetext{
${ }^{5}$ Hodges [6], 261.

${ }^{6}$ Farhang [4].

${ }^{7}$ Reforming Civil Litigation Funding and Costs in England and Wales-Implementation of Lord Justice Jackson's Recommendations. The Government Response (Ministry of Justice, 2011).

${ }^{8}$ Ibid.

${ }^{9}$ See Report by Hodges, Peysner, Nurse [18].
} 
Within the technical rules of a collective court procedure, there are also other levers, such as:

a. prioritization of pathways: the collective judicial procedure should not be used if other preferable options exist;

b. restriction on use of the procedure to approved personnel;

c. evaluation of the merits;

d. certification by the court;

e. opt-out or opt-in;

f. notice provisions requiring notice to be given to all class members of the existence of an action and/or of a settlement, so they can opt-in or opt-out;

g. court approval of a settlement;

h. court approval of lawyers' fees;

i. stand-alone or follow-on model.

However, none of these levers can be calibrated, either individually or cumulatively. You cannot design a system to give 'just enough' safeguards and no more. You will end up with either too little or too much enforcement (under-restitution or overdeterrence), and this will vary between types of claim and sectors. If you pull more levers, you will get more-or less-litigation. That is what is happening now, often unplanned and uncontrolled, in some Member States.

In these respects, there is no difference between enforcement of competition law, consumer law, or any other area of law. The procedural levers and their economic effect are exactly the same, but their magnitude will vary from sector to sector.

\subsection{Major events}

The following is a summary of the major events in the history of collective redress in Europe. ${ }^{10}$ Firstly, let us look at Member State level. Fourteen of the 27 Member States have judicial collective redress mechanisms in which damages can be claimed, ${ }^{11}$ but they have been found to be very different and to have diverse results. ${ }^{12}$ The studies and consultations showed that

the vast majority of the existing collective redress mechanisms tend to have some elements that work, and some that do not. Almost all existing collective redress mechanisms have some added value compared to individual judicial redress and alternative dispute resolution schemes. But their efficiency and effectiveness could be improved. The mechanisms have been applied in relatively few cases. ${ }^{13}$

Many of the national models have deliberately been designed conservatively, to avoid introducing large economic incentives for lawyers that might result in unmerited litigation and abusive practices. The Swedish Class Actions Law, which was based on

\footnotetext{
${ }^{10}$ Hodges [8], 96-123; Hodges [14], Hodges [9], 41-66.

${ }^{11}$ See national reports of the Stanford-Oxford Global Network on Class Actions at globalclassactions. stanford.edu.

${ }^{12}$ See Hodges [14]; Hodges [9] and Cafaggi, Micklitz [3].

${ }^{13}$ Consumer Green Paper, supra note 15 , at para. 12.
} 
the US model, was enacted without the inclusion of contingency fees and no loser pays rule, as originally proposed. A recent example is the Polish Class Action Law, which included various safeguard features, such as maintaining the loser pays rule, the ability for a defendant to request an order that the representative claimant post a deposit against the costs, the requirement that all claimants must claim the same amount in damages, the exclusion of non-pecuniary tortious claims, and a limit of $20 \%$ on contingency fees.

The European Commission has proceeded carefully, and run into political difficulties. A 2008 consultation on benchmarks ${ }^{14}$ was followed by a Green Paper on consumer collective redress, ${ }^{15}$ which made no statement on the outcome of the consultation on benchmarks, or on any further or revised proposed benchmarks, but was accompanied by a Questions and Answers document ${ }^{16}$ and two studies by external contractors: a Problem Study, ${ }^{17}$ which evaluated the problems faced by consumers in obtaining redress, and the economic consequences; and an Evaluation Study, ${ }^{18}$ which evaluated the effectiveness and efficiency of existing collective redress mechanisms in the EU.

The Commission concluded in 2008:

Studies ... have shown that there is no easy answer to the problem. All the current redress systems have their strengths and weaknesses and no single mechanism is ideal for all types of claims. ${ }^{19}$

By 2008, the terminology had changed twice. The first change was from 'class actions' to a European term 'collective actions'. This signified a political desire to distance whatever technique might be proposed in Brussels from the 'US class action', which had become a 'toxic term'. Far more significantly, the second change was from 'collective actions' to 'collective redress'. This signified a growing re-examination of the essential underlying policy goals, going back to first principles, and re-examining all available technical options. It was realised that the assumption that a judicial procedure was the only option was not only untrue, and that other options existed, but also that it was the wrong place to start.

By 2008, the debate on collective redress had crystallised in two different economic sectors: consumer redress and competition damages. These are different areas,

\footnotetext{
${ }^{14}$ See online: http://ec.europa.eu/consumers/redress_cons/collective_redress_en.htm\#Benchmarks. The benchmarks have been criticized as assuming that the solution would be a judicial solution, and the Commission has privately accepted that view. Hodges [15].

${ }^{15}$ Green Paper on Consumer Collective Redress, COM(2008) 794, 27.11.2008, online: http://ec.europa.eu/ consumers/redress_cons/collective_redress_en.htm.

${ }^{16} \mathrm{MEMO} / 08 / 741,27.11 .08$.

${ }^{17}$ Study regarding the problems faced by consumers in obtaining redress for infringements of consumer protection legislation, and the economic consequences of such problems, by Civic Consulting and Oxford Economics, 2008, online: http://ec.europa.eu/consumers/redress_cons/finalreportevaluationstudypart1final2008-11-26.pdf.

${ }^{18}$ Study on the Evaluation of the effectiveness and efficiency of Collective Redress mechanisms in the European Union, by GHK, Civic Consulting and Van Dijk Management Consultants, online: http://ec. europa.eu/consumers/redress_cons/finalreport-problemstudypart1-final.pdf.

${ }^{19}$ MEMO/08/741, p. 3.
} 
in which different existing architectures exist for enforcement and redress. But the two areas became intertwined in the political debate. The consumer redress area had a long history, stretching back to the 1960s, in which consumer interests had long called for a class action to be introduced so as to address mass consumer problems.

Debate on the competition side has been about how to deliver damages after breach of competition law. The right to damages was recognised in EU law only in 2001. ${ }^{20}$ It appeared that damages were not widely being paid, ${ }^{21}$ mainly because of a series of difficulties over bringing claims, such as:

- access to documents to establish liability and quantum, especially those held by the authorities in their enforcement activities. There was concern that the 'leniency programme' would be undermined if leniency documents were made available to claimants;

- overcoming the considerable complexities of quantifying losses in competition cases, including the extent to which a 'passing on' defence should be available;

- how to deal with multiple similar cases.

These issues were canvassed in a 2005 Green Paper $^{22}$ and a 2008 White Paper. ${ }^{23}$ A central proposal was to introduce two collective procedures, one a representative action and one a class action, clearly very similar to the American model.

Thus, the question on the competition side is: given that the approach to enforcement has been solely to rely on (ever increasing) fines, and it appears that damages have frequently not been claimed under the national legal systems, how can damages be claimed more frequently? The European Commission's answer to that question has been to leave the public enforcement policy intact, and to propose to 'bolt on' a separate system of rules to facilitate a privatised approach for claiming damages in private actions.

These proposals were met with vehement opposition by the German and French governments, the business community, ${ }^{24}$ and some academic commentators, ${ }^{25}$ although widely supported by lawyers, and by many competition economists. In the

\footnotetext{
${ }^{20}$ Case C-453/99 Courage and Crehan [2001] ECR I-6297.

${ }^{21}$ Waelbroeck, Slater, Even-Shoshan [30]. More recent data, notably from Germany, indicates that the level of claims and/or settlements is higher than thought and appears to be increasing.

${ }^{22}$ Green Paper: Damages actions for breach of the EC antitrust rules, COM (2005) 672, 19.12.2005; Commission Staff Working Paper: Annex to the Green Paper 'Damages actions for breach of the EC antitrust rules', SEC (2005) 1732, 19.12.2005.

${ }^{23}$ European Commission (EC), 'White Paper on damages actions for breach of the EC antitrust rules' $\operatorname{COM}(2008) 165,2.4 .2008$. Commission Staff Working Paper accompanying the White Paper on damages actions for breach of the EC antitrust rules, SEC(2008) 404 ('Staff Working Paper'). Commission Staff Working Document accompanying the White Paper on damages actions for breach of the EC antitrust rules: Impact assessment, SEC(2008) 405 ('Impact Assessment Report').

${ }^{24}$ Letter from the Presidents of the Association of German Chambers of Industry and Commerce (DIHK), the Association of German Banks (BdB) and the German Insurance Association (GDV) to President Barroso, 8 May 2009.

${ }^{25}$ Wils [32] 473-488; Kortmann, Swaak [22]. The latter is a strong attack on DG COMP's proposals, arguing that they will lead to 'overcompensation' and messing up national rules, especially in relation to 'passing on' of loss and limitation periods. They do not see empirical evidence on which to found a proposal.
} 
last days of the Commission in 2009, Competition Commissioner Kroes failed in her attempt to table a legislative proposal. ${ }^{26}$

One aspect that is common to the consumer and competition situations is that mass problems can frequently involve widespread but small losses to many people. No rational individual would institute an individual court proceeding to recover a small sum of money, especially where the issues might be complex. It is rational, therefore, to ask whether mass individual claims can be combined in a procedure that delivers 'judicial economy' and thereby increases access to justice. The US class action, largely copied in Canadian Provinces and Australia, provides efficiency by having just a single claimant that represents all other members of the class. In Canada and Australia, however, there is the problem that the representative claimant bears the full risk of liability for opponents' costs under the loser pays rule. This has a chilling effect on rates of litigation, although the business models and available capital of some Australian 'third party' funders can cover with this financial risk.

When the new Commission was in place in 2009, President Barosso instructed his Commissioners for Competition and Consumer Affairs, and joined by the Commissioner for Justice, to collaborate in drawing up a unified policy on collective redress. ${ }^{27}$ A further consultation paper was issued in $2009,{ }^{28}$ in which the Commission said:

US style class action is not envisaged. EU legal systems are very different from the U.S. legal system which is the result of a "toxic cocktail"-a combination of several elements (punitive damages, contingency fees, opt-out, pre-trial discovery procedures).... This combination of elements-“toxic cocktail"should not be introduced in Europe. Different effective safeguards including, loser pays principles, the judge's discretion to exclude unmeritorious claims, and accredited associations which are authorised to take cases on behalf of consumers, are built into existing national collective redress schemes in Europe.

All the Green Paper options, and in particular a possible EU collective procedure outlined above, reflect EU legal traditions. The Commission seeks to encourage a competitiveness culture e.g. where businesses which play by the rules can realise their competitive advantages, not a litigation culture. ${ }^{29}$

The Commission intends to publish a policy statement on collective redress following the 2009 consultation paper. This will be published after the Commission has considered an opinion from the European Parliament, which is expected in late 2011. ${ }^{30}$

\subsection{Some empirical evidence}

A threshold issue is to identify what level of need there is for mass redress, and how much of a problem exists with existing techniques. There is virtually no reliable

\footnotetext{
${ }^{26}$ N. Tait, 'Future of European antitrust proposals in doubt', Financial Times, 3 October 2009.

${ }^{27}$ Towards a Coherent European Approach to Collective Redress: Next Steps. Joint information note by Vice-President Viviane Reding, Vice-President Joaquín Almunia and Commissioner John Dalli, 5.10.2010, available at http://ec.europa.eu/transparency/regdoc/rep/2/2010/EN/2-2010-1192-EN-1-0.Pdf.

${ }^{28}$ Online: http://ec.europa.eu/consumers/redress_cons/docs/consultation_paper2009.pdf.

${ }^{29}$ European Commission DG SANCO, MEMO/08/741, p. 4.

${ }^{30}$ The rapporteur is KH Lehne MEP.
} 
data ion the former question. The 2008 Evaluation Study found that the evidence on individual economic detriment was low. The average consumer detriment recovered per litigant was $€ 41$ in those states with collective judicial mechanisms, and was $€ 18$ for all consumers in those states without a procedure. Granted that those figures may not be directly comparable, the difference that introduction of a court-based collective procedure might be expected to bring was $€ 23$ per consumer per annum. A figure of $10 \%$ of collective redress claims having a cross-border element is far from overwhelming, although the effect depends on the total economic detriment. A total of 326 cases in 13 jurisdictions over roughly ten years (which is an over-estimate, since the mechanisms have not existed for that long in some jurisdictions) gives a rough annual average of 32.5 cases per year. That would equate to 3 or 4 crossborder cases a year. It is, of course, likely that although individual detriment may be low (and would result in rational economic behaviour that individual claims would not be attractive), the combined economic benefit to individual traders of retained illicit profit from infringements may be high, and the market thus distorted. That observation prompts the question of whether the problem, and hence the solution, might be a market regulatory problem rather than a redress problem.

Do collective actions work? Do they deliver mass solutions, quickly, cheaply, and affect defendants' behaviour? It may be too soon to evaluate the collective action rules that have been adopted in the past decade in Member States. But initial results are not encouraging. Collective actions take too long, and are too expensive. The experience of product liability cases in England shows that many failed because of poor merits, and lasted several years. ${ }^{31}$ The German litigation of Deutsche Telekom investors under the 2005 Capital Investors Class Action Law (KapMuG) is likely to continue for 10 years. In contrast, the Dutch approach, based on incentivising parties to negotiate settlement of their disputes, which are then made binding by the court, has proved to be attractive and largely efficient. ${ }^{32}$

\subsection{Constitutional issues}

Two critical technical issues need to be noted. Firstly, many Continental jurisdictions have inherent resistance to adopting an opt-out model, since this offends the principle of individual determination over legal rights, which is contrary to principles of fundamental rights. ${ }^{33}$

Secondly, institutional barriers exist to development of an EU enforcement policy, resting partly on the principle of subsidiarity ${ }^{34}$ but more on that of procedural auton-

\footnotetext{
${ }^{31}$ Hodges [10]. The largest mass litigation in England in the past decade, over injuries allegedly caused by the MMR vaccine, took 10 years and then collapsed before trial when it was clear that the vaccine was not the cause of the claimants' conditions.

${ }^{32} 2005$ Class Action Settlement Law (WCAM).

${ }^{33}$ See Council of Europe, European Convention on Human Rights (1951); Charter of Fundamental Rights of the European Union (2000) at http://www.europarl.europa.eu/charter/default_en.htm.

${ }^{34}$ Introduced into EU legislation by the Treaty on European Union, art 5.3.: see http://www.europarl. europa.eu/parliament/expert/displayFtu.do?language=en\&id=74\&ftuId=FTU_1.2.2.html.
} 
omy. ${ }^{35}$ The latter upholds a constitutional settlement that competence over enforcement of Community rules lies with Member States: the national obligation is merely to achieve the effect by means that are proportionate, effective and dissuasive. The proportionality principle has particular importance in the debate on the addition of fines to damages in relation to competition infringements, without some fundamental reassessment of their combined effect.

\subsection{The new policy for enforcement, redress, and incentivising behaviour}

Hodges has suggested a new, integrated policy for enforcement and redress, which relies on a three pillar model. ${ }^{36}$ He suggests that the starting point is to define the basic objectives that society wishes to achieve, which he states as:

1. setting the basic standards of expected behaviour;

2. seeking to prevent things going wrong;

3. putting things right when they go wrong.

It is axiomatic that where there is liability, there must be redress. The issue then is what techniques can be used. The available techniques, and combinations of techniques, should be evaluated against criteria (especially speed, cost and ability to deliver desired outcomes).

In delivering objectives 2 and 3 above, Hodges' model adopts the following three pillars:

Pillar 1: enforcement by public authorities, through use of wide-ranging and powerful sanctions, with both public and private techniques, subject to democratic and court controls.

Pillar 3: enforcement by private actors through use of private actions through the courts.

Pillar 2: direct negotiation and resolution of issues, assisted by independent ADR pathways.

Use of pillar 2 would be incentivised through the existence of pillars 1 and 3 . The ability of a regulator or a court to impose a solution (individual or mass) would frequently encourage parties to use ADR services. The pillar 1 power may therefore be rarely used, thereby saving resources. In order to avoid the risk of abusive capture of a pillar 3 pathway by rent-seeking intermediaries, it would only be available where a court considers that its use is reasonable, given the availability of a pillar 1 or 2 option.

The OECD recommends that all states should adopt mechanisms that enable consumers to be able to resolve disputes effectively, whether individually, collectively or

\footnotetext{
${ }^{35}$ Storskrubb [27], p. 19; Andenas [1], 7-24; van Gerven [29], Prechal [25]; Kakouris [20]. For limitations to this autonomy, through the principles of equivalence and effective protection, see cases: Case 33/75 Rewe-Zentralfinanz e G et Rewe-Zentral AG v Landwirtschaftskammer für das Saarland [1976] ECR 01989; Case 45/76 Comet BV v Produktschap voor Siergewassen [1976] ECR 02043. A more recent case: C-446/04 Test Claimants in the FII Group Litigation v Commissioners of Inland Revenue 12 December 2006, OJ C 331 of 30.12 .2006 , p. 5.

${ }^{36}$ See Hodges [13], 1.
} 
through public authorities, and its stressing of a need for a combination of mechanisms, and for direct negotiation as the first option. ${ }^{37}$

Experience from the Danish Consumer Ombudsman, and the British telecommunications regulator Ofcom and Financial Services Authority ${ }^{38}$ shows how quickly, efficiently and effectively a pillar 1 power can deliver both mass redress and behaviour control impacts. Since it should be the primary duty of a regulator to see that markets remain balanced, that duty necessarily includes a duty to ensure that restitution is made, since this is an essential requirement for achieving rectification of balance after a mass infringement has occurred. Accordingly, redress, and rectification of the market, should pre-cede the imposition of sanctions. This is contrary to the system under which EU competition fines are imposed: in concentrating solely on the enforcement policy based solely on deterrence, DG COMP has missed the essential objective. ${ }^{39}$ It is anticipated that at least one major Member State will soon follow Denmark, and diverge from the DG COMP approach to enforcement, by giving its national regulator a pillar 1 collective damages power, and encourage the private sector to construct and operate a viable ADR scheme for competition damages.

We need redress, but the collective action on its own is an old-fashioned tool for delivering this. Litigation is always slow and expensive. There are more effective ways of delivering redress and behaviour, which are cheap, fast and effective.

\section{Consumer ADR}

Debate about alternate dispute resolution (ADR) is far more recent than the debate about collective redress, but it has spread quickly. ADR largely first arrived in Europe in the 1990s from the United States (again) and also from use in disputes in Canada, Australia and New Zealand between indigenous peoples and settlers' descendants. ${ }^{40}$ The main reason for building an ADR system arises from concern that the courts are too slow and expensive. But other features of ADR systems can influence decisions, such as a desire for confidentiality, greater informality, and other outcomes such as restoring peaceful relationships through a process that is not adversarial or bipolar (one side wins, the other loses) but less aggressive and more consensual. Arbitration of commercial disputes, nationally and internationally, is a familiar long-established ADR technique.

The current over-riding economic imperatives of governments are highly relevant. In order to rescue the economy, governments have to cut public expenditure and incentivise the growth of private business. They do not want to impose unnecessary

\footnotetext{
${ }^{37}$ OECD Recommendation on Consumer Dispute Resolution and Redress (Paris: OECD, 2007) at http:// www.oecd.org/dataoecd/43/50/38960101.pdf.

${ }^{38}$ s. 404 of the Financial Services and Markets Act 2000. The enforcement policy, based on 'restorative justice' principles (rather than a deterrence theory) prioritises disgorgement (restitution), discipline (penalties for offenders) and deterrence, in that order. See http://www.fsa.gov.uk/pages/Library/Communication/PR/ 2010/036.shtml; FSA consultation paper [CP09/19] on enforcement of financial penalties at http://www. fsa.gov.uk/pubs/cp/cp09_19.pdf.

${ }^{39}$ Hodges [7], 383.

${ }^{40}$ See Roberts, Palmer [26]; Menkel-Meadow [24].
} 
transactional costs (through unnecessary regulation or litigation) on business, but they do want competitive and hence innovative markets, in which the rules are observed. Increasing emphasis has been placed on extra-judicial dispute resolution, since this may be particularly relevant for small claims by consumers and SMEs.

At EU level, measures started with two recommendations on standards for mediation, and have progressed to more formal structures:

- In 1998 the Commission published a communication on "out-of-court settlement of consumer disputes." 41

- In April 2002 the Commission launched a Green Paper on ADR.

- A 1998 Recommendation on the principles applicable to out-of-court settlement of litigation, including (a) minimum criteria guaranteeing the impartiality of the body, the efficiency of the procedure and the publicising and transparency of proceedings and (b) the principles of independence, transparency, adversarial, effectiveness, legality, liberty and representation. ${ }^{42}$

- A 2001 Recommendation on the principles for out-of-court bodies involved in consensual resolution of consumer disputes, including the principles of impartiality, transparency, effectiveness, fairness. ${ }^{43}$

- In 2001, an Extra-Judicial Network (EEJ-Net) was launched ${ }^{44}$ and a consumer claim form promulgated ${ }^{45}$ to facilitate consumers' access to ADR providers. ${ }^{46}$ Subsequently renamed the European Consumer Centres, the ECC-Net consists of national 'clearing houses' that assist consumers to settle possible cross-border disputes with companies, by guiding them towards alternative dispute resolution mechanisms. ${ }^{47}$ From 2006-2009, most complaints tackled by ECCs concerned products and services, and contract terms. The main sector concerned by far over those five years was air transport, and a large number of complaints also concerned on-line transactions $(55 \%){ }^{48}$ The total number of complaints handled by ECCs has been between 50,000 and 60,000 annually.

- A separate network of national ADR bodies was established 2001 for financial services, called FIN-NET (Financial Services Complaints Network). ${ }^{49}$ FIN-NET links 50 out-of-court schemes that deal with complaints in the area of financial

\footnotetext{
${ }^{41} \mathrm{http} / / /$ ec.europa.eu/consumers/redress/out_of_court/commu/index_en.htm.

${ }^{42}$ Commission Recommendation 98/257/EC on the Principles Applicable to the Bodies Responsible for Out-of-Court Settlement of Consumer Disputes, [1998] OJ L 155/31, online: http://eur-lex.europa.eu/ LexUriServ/LexUriServ.do?uri=OJ:L:1998:115:0031:0034:EN:PDF.

${ }^{43}$ Commission Recommendation 2001/310/EC on the Principles for Out-of-Court Bodies involved in the Consensual Resolution of Consumer Disputes, [2001] OJ L 109, 56-61, http://eur-lex.europa.eu/Lex UriServ/LexUriServ.do?uri=OJ:L:2001:109:0056:0061:EN:PDF.

${ }^{44}$ Council Resolution of 25 May 2000 on a Community-wide network of national bodies for the extrajudicial settlement of consumer disputes, OJ C 155/1, 6.6.2000.

45 http://www.eejnet.org/filing_complaint.

${ }^{46}$ http://ec.europa.eu/consumers/publications/factsheet-ECC-Net_en.pdf (accessed 31 March 2011).

${ }^{47}$ http://europa.eu/legislation_summaries/other/132043_en.htm.

${ }^{48}$ See the ECC Network website consulted in 2011 http://ec.europa.eu/consumers/ecc/key_facts_figues_ en.htm

${ }^{49}$ See http://ec.europa.eu/internal_market/finservices-retail/finnet/index_en.htm (accessed July 2008).
} 
services and covers the European Union, Norway, Iceland and Liechtenstein. In 2009, FIN-NET handled 1,523 cross-border cases, of which 884 were in the banking sector, 244 in the insurance sector, 410 in the investment services sector, and 4 that could not be attributed to one sector. ${ }^{50}$

- In 2002 SOLVIT $^{51}$ was created as a free-of-charge on-line problem solving network in which EU Member States work together to solve without legal proceedings problems caused by the misapplication of Internal Market law by public authorities. There is a SOLVIT centre in every European Union Member State (as well as in Norway, Iceland and Liechtenstein). SOLVIT Centres can help with handling complaints from both citizens and businesses. They are part of the national administration and are committed to providing real solutions to problems within ten weeks. From 2002 to 2010 SOLVIT resolved more than 1300 problems encountered by citizens and businesses due to incorrect application of EU rules by national authorities. It accepts around 60 new cases per month, around $80 \%$ of which are resolved, most of them within the deadline of ten weeks.

- A 2004 Voluntary European Code of Conduct for Mediators, covering:

- Competence, appointment, fees of mediators.

- Independence and impartiality.

- Ensuring the understanding by the parties, fairness, informed consent over any agreement reached, parties' freedom to withdraw.

- Confidentiality. ${ }^{52}$

- The European Small Claims Procedure, for cross-border claims under $€ 2,000$, in force from January 2009, which does not require representation by a lawyer but in which the loser must pay costs. ${ }^{53}$ This regulation eliminates the intermediate step of requiring the recognition of the case and its enforcement in another state. However, a 2007 study has shown that the cost, length or complexities of these procedures are still too high to allow effective access to justice. ${ }^{54}$

- The Directive on mediation, in force from 21 May 2011, which promotes voluntary mediation as a viable alternative to litigation in providing access to justice, and includes requirements on confidentiality of processes, and enforceability of agreements. ${ }^{55}$ However, it applies to cross-border mediation only.

- In May 2010 a Recommendation introduced an EU-wide method for classifying and reporting consumer complaints to be used by complaint bodies on a volun-

\footnotetext{
${ }^{50}$ This number is based on the reporting from 38 members of FIN-NET in 2009.

${ }^{51}$ http://ec.europa.eu/solvit/site/index_en.htm.

${ }^{52}$ Online: http://europa.eu.int/comm.justice_home/ejn/adr_ec_code_conduct_en.pdf.

${ }^{53}$ EC, Commission Regulation (EC) 861/2007 of the European Parliament and of the Council of 11 July 2007 establishing a European Small Claims Procedure, [2007] O.J. L 199/1, see art 2 and Annex 1 art. 7. The legal basis under art. $61 \mathrm{EC}$ for coverage of domestic disputes as well as cross-border ones was a matter of debate. Art 16 provides that the court shall not award costs to the extent that they were unnecessarily incurred or are disproportionate to the claim. See Haibach [5], 293-601; Hondius [19], 131 et seq.; Baldwin [2], 313-343; Whelan [31](ed.), 253 et seq.

${ }^{54}$ See Stuyck [28], below.

${ }^{55}$ EC, Commission Directive 2008/52/EC of the European Parliament and of the Council of 21 May 2008 on certain aspects of mediation in civil and commercial matters, [2008] O.J. L 136/3.
} 
tary basis. ${ }^{56}$ This Recommendation is part of the gradual planned establishment of an EU harmonized complaint classification system and a Union-wide database of consumer complaints. The harmonised methodology is to be used on a voluntary basis by complaints bodies. 57

It was realised around the end of the 2000s that ADR can deliver effective redress for consumers, and that ADR systems can deliver mass redress, which goes a long way to solving consumer collective redress problems. There is wide political support for extending consumer ADR, but there remains strong opposition to extending collective actions, so the choice for political leaders is transparently clear.

Various national rules of civil procedure have been amended in the last decade to extend the use of mediation for court-based claims. The influential pioneer was England and Wales in the fundamental reform of the Civil Procedure Rules introduced in 1999. ${ }^{58}$ However, a key feature of the English reform was to combine court procedure with mediation, and make settlement a formal goal of civil process. Those civil law systems that implement the Mediation Directive but fail to integrate it with civil procedure may struggle to realise benefits.

DG SANCO commissioned a series of studies on consumer ADR. A 2005 study led by Professor Jules Stuyck published in 2007 mapped ADR in 28 Member States plus USA, Canada and Australia. ${ }^{59}$ It found that a multitude of ADR methods are used, that every Member State had put in place an unique mix. From this divergence, it was far from self-evident how to come up with one 'ideal' ADR system. Gaps were identified in sectoral and geographical coverage, ${ }^{60}$ leading to the conclusion that an ADR scheme with general competence and guaranteed geographical coverage was a necessary complement for sector specific mediation and arbitration schemes.

A 2009 study for the Commission found that there are far more ADR systems than most people are aware of: ${ }^{61}$

- 750 national ADR business-to-consumer (B2C) schemes were identified across the EU. The most were: Germany 247 (many decentralised schemes), Italy 129 and UK 43, France 35. Civic say that ADR is clearly more relevant in Belgium, UK, Spain, Sweden, Austria, Ireland, Netherlands, Denmark and Malta than elsewhere. UK seems to have the highest number of cases for any individual scheme, with the Financial Ombudsman Service (FOS) often handling over 100,000 cases a yearmost large schemes handle 5,000 to 20,000 pa. There seemed to be 530,000 cases in the EU in 2008, and this increased from 410,000 in 2006.

\footnotetext{
${ }^{56}$ See the recommendation at http://ec.europa.eu/consumers/strategy/complaints_en.htm

${ }^{57}$ See the recommendation at http://ec.europa.eu/consumers/strategy/complaints_en.htm.

${ }^{58}$ Pursuant to Lord Woolf [34].

${ }^{59}$ Stuyck et al. [28] available at: http://ec.europa.eu/consumers/redress/reports_studies/index_en.htm.

${ }^{60}$ Examples quoted at para 118 include no coverage for air transport disputes, car rental, sports centres and computer stores in the Netherlands despite the existence of 30 sector specific arbitration schemes there. Ombudsman in UK are said to be quite popular but are mainly present in the services sector and not goods.

${ }^{61}$ Civic Consulting, Study on the use of Alternative Dispute Resolution in the European Union, 16 October 2009 http://ec.europa.eu/consumers/redress_cons/adr_study.pdf 2 December 2009.
} 
- Schemes have a high degree of diversity, as between public and private origins, and over the extent to which a decision or recommendation is binding on one or both parties. Several types of collective ADR procedures are in use, notably involving investigations, single representative procedures, and Scandinavian ombudsmen. Concerns over the functioning of collective cases include (a) the complexity of the procedure and related costs and (b) the non-binding nature of the decision.

- ADR schemes are low-cost and quick for consumer disputes. The vast majority are free or minimal cost to consumers (below $€ 50$ ) and are settled within a short period of time (an average of 90 days ${ }^{62}$ ). 'The analysis shows that many problems connected with court proceedings can be solved by effective ADR schemes, such as cost, duration of proceedings and formality.'

ADR is assuming increasing importance in EU law. In addition to the Mediation Directive mentioned above, measures that encourage Member States to establish ADR schemes are:

- the E-commerce Directive ${ }^{63}$

- the Postal Services Directive ${ }^{64}$

- the Markets in Financial Instruments Directive (MiFID) ${ }^{65}$

EU legislative frameworks that require that adequate and effective ADR schemes are put in place:

- the telecom sector ${ }^{66}$

- the energy sector ${ }^{67}$

- the Consumer Credit Directive ${ }^{68}$

- the Payment Services Directive. ${ }^{69}$

The Services Directive ${ }^{70}$ requires service providers to provide consumers with information if they are members of an ADR scheme.

The number of ADR schemes that already exist is surprisingly large. Such schemes operate primarily within individual sectors (such as financial services, holidays, energy, telecoms) and have, therefore, arisen largely unnoticed except outside their particular sector. But the result is startling. Over 100,000 financial services claims in the UK do not go to court annually but are processed by the Financial Ombudsman Service. Around 11,000 claims are processed annually by the 50 sectoral

\footnotetext{
${ }^{62}$ Ibid, p. 33.

${ }^{63}$ Directive No 2000/31/EC; OJ, L 178, 17.7.2000, p. 1.

${ }^{64}$ Directive No 2008/6/EC; OJ L 52 27.02.2008, p. 3.

${ }^{65}$ Directive No 2004/39/EC; OJ L 145/1, 30.4.2004, p. 33.

${ }^{66}$ Directives No 2009/136/EC and No 2009/140/EC; OJ L337, 18.12.2009, pp. 11 \& 37.

${ }^{67}$ Directives No 2009/72/EC and No 2009/73/EC; OJ L 211, 14.8.2009, pp. 55 \& 94.

${ }^{68}$ Directive No 2008/48/EC; OJ L 133, 22.5.2008, p. 66.

${ }^{69}$ Directive No 2007/64 /EC; OJ L319/1, 5.12.2007, p. 32.

${ }^{70}$ Directive No 2006/123/EC; OJ L 376, 27.12.2006, p. 36.
} 
dispute Boards in the Netherlands. In Finland, Sweden, Norway and Denmark, virtually no medical negligence or product liability litigation has appeared in the courts for many years, since the introduction of no fault compensation schemes. ${ }^{71}$ And so on. This raises the issue of what the residual function may be for the courts.

In January 2011 the Commission issued a consultation on ADR and on possible ways in which the use of ADR within the EU could be improved, ${ }^{72}$ noting that

ADR has, however, not yet achieved its full potential. In 2009, 6.6\% of the cross border complaints received by the European Consumer Centre network were transferred to an ADR scheme.

\section{The current state of consumer ADR}

There is still widespread confusion about what consumer ADR actually is. Forthcoming research from Oxford identifies that mechanisms involve consumer ombudsmen or similar service providers (not mediation attached to the court process, and not usually separate arbitration). ${ }^{73}$

The following issues need to be addressed:

1. To review the essential requirements that are contained in the 1998 and 2001 Recommendations, and update them. Are the principles of independence, impartiality, transparency, fairness, hearing both sides, effectiveness, legality, liberty and representation still the right ones?

2. To evaluate all ADR schemes against those criteria, and to facilitate or ensure that all schemes observe the essential requirements and adopt best practice.

3. To address structural issues, notably: how to encourage business to join and fund ADR schemes; how to extend the coverage of ADR schemes to more sectors; how to provide effective cross-border solutions.

An example of issue 2 is: Can private sector dispute resolution schemes be independent and unbiased? Techniques have developed to achieve this. They rely first on applying the essential requirements through combinations of vertical scrutiny by regulators and customers, and horizontal scrutiny by competitors, the market and the media. Leading examples are the criteria and systems established in the United Kingdom for the telecommunications sector by Ofcom and general consumer sector by the Office of Fair Trading, ${ }^{74}$ and established in the Netherlands by the Stichting Geschillencommissie.

\footnotetext{
${ }^{71}$ Hodges [11], 143-175.

${ }^{72}$ Consultation paper on the use of Alternative Dispute Resolution as a means to resolve disputes related to commercial transactions and practices in the European Union (European Commission, January 2011), available at http://ec.europa.eu/dgs/health_consumer/dgs_consultations/ca/docs/adr_consultation _paper_18012011_en.pdf.

${ }^{73}$ Hodges, Benöhr, Creutzfeld-Banda [17].

${ }^{74}$ See Mapping UK consumer redress. A summary guide to dispute resolution systems (Office of Fair Trading, May 2010), http://www.oft.gov.uk/shared_oft/general_policy/OFT1267.pdf.
} 
A topical issue is whether ADR can be mandatory, or whether this infringes the right of access to the courts under art 6 ECHR. An interesting case ${ }^{75}$ was decided by the Court of Justice in relation to Italian implementation of the Universal Services Directive (USD) ${ }^{76}$ requiring that Member States shall ensure that transparent, simple and inexpensive procedures are drawn up for dealing with users' complaints, and the general principle of effective judicial protection were compromised by the Italian law which made mandatory an initial out-of-court dispute resolution procedure before a dispute was admissible in the ordinary court process. The Court ruled that the USD does not set out the precise content or the specific nature of the out-of-court procedures that have to be introduced at the national level. The only criteria were those set out in article 34 of the USD: the principles of effectiveness, legality, liberty and representation. The Court held that none of these principles limited the power of the Member States to create mandatory out-of-court procedures for the settlement of telecoms disputes between consumers and providers. ${ }^{77}$ The only requirements are the maintenance of the right to bring an action before the courts for the settlement of disputes and for ensuring that the Directive remains effective.

Almost all of the ADR systems use one or more of the same basic dispute resolution techniques of mediation, conciliation and arbitration. Many systems are designed to integrate several techniques within a tiered sequence, so as to enable different forces to act together within a pyramid structure within which claims can be resolved first in the quickest and cheapest fashion, whilst allowing progression to more adjudicatory (and hence more costly and slower) techniques involving adjudication by arbitrator(s) or judge(s):

a. direct negotiation between the parties;

b. conciliation or mediation assistance from a trade association, ombudsman or independent party;

c. the option of referral to a binding decision by an independent third party through arbitration (by an arbitrator, dispute resolution board, or ombudsman), as an alternative to starting a judicial procedure.

Those involved in stages (b) and (c) have sector-specific expertise, and the ability to adopt proportionate procedures, thereby delivering expert, swift and low cost outcomes. Sectoral Boards, such as travel/holidays, financial services, telecommunications, motor vehicles, and so on, can be structured so as to satisfy requirements of independence and absence of capture.

A significant percentage of initial consumer complaints (varying from sector to sector) are requests for information about how to use products and services appropriately or better, rather than disputes. If such inquiries are not dealt with well, they can escalate into disputes. There is, therefore, a need for an early information service and support function, and this is usually best provided by business entities.

\footnotetext{
${ }^{75}$ See J. Davies and E. Szyszczak, ‘ADR: Effective Protection of Consumer Rights?' (2010) 35 E.L. Rev. October 2010-11-19.

${ }^{76}$ Directive 2002/22 [2002] OJ L108/51.

${ }^{77}$ Alassini (C-317/08, C-317/08, C-319/08 and C-320/08) March 18, 2010 at [34].
} 
Another challenge for Europe is to enhance the existing national ADR systems and create a powerful unified pan-EU mechanism. A good precedent exists in the Netherlands, where a unified national system of sectoral complaint Boards exists. What is needed is a single model that can be applied in every business sector. That would increase consumer knowledge of the existence of trustworthy dispute resolution systems, increase throughput, and pressure business sectors to establish schemes and pressure traders to join them. Cross-border claims can be handled by joining up national ADR systems through building on the existing ECC-NET and FIN-NET networks.

Importantly, the best ADR systems can also provide regulatory information and effects, if designed properly. The dispute resolution procedures can deliver valuable information on types of claims, trends and issues, and how well sectors and individual businesses are performing, both in relation to substantive issues such as breach of law, or commercial information on how to improve products and services, as well as whether there is a need to improve the dispute handling process itself. This can improve standards and provide a powerful mechanism for behaviour control. The requirement is that the dispute resolution system should capture the data, and make it transparent and available to the market, customers and regulators. Economies of scale can also be achieved in combining dispute resolution systems within quality control and regulatory systems. Hence, the dispute resolution system can operate also as a Quality Management System, reinforcing and improving virtuous behaviour.

\section{The 2011 Commission ADR and ODR proposals}

On 29 November 2011 DG Sanco issued a Communication ${ }^{78}$ and two legislative proposals, one a draft Directive on $\mathrm{ADR}^{79}$ and the other a draft Regulation on ODR. ${ }^{80}$ The Commission's objective was 'to improve the functioning of the retail internal market and more particularly to enhance redress for consumers'. Both proposals are based on Article 114 TFEU.

The following statements were made in the Communication:

- The vast majority of ADR procedures are free of charge for consumers or of moderate costs (below $€ 50$ ). Most disputes submitted to ADR entities are decided within 90 days.

- Most consumers who have used ADR recall it as a straightforward and transparent process where support and advice was provided. Hence, consumers are more willing to resolve disputes through ADR than through court proceedings. Businesses also prefer resolving disputes through ADR, and those businesses which have already used ADR would use it again in the future.

\footnotetext{
${ }^{78}$ Communication from the Commission. Consumer solutions in the Single Market, COM(2011) 791/2.

${ }^{79}$ Proposal for a Directive of the European Parliament and of the Council on alternative dispute resolution for consumer disputes and amending Regulation (EC) No 2006/2004 and Directive 2009/22/EC (Directive on consumer ADR), COM(2011) 793/2.

${ }^{80}$ Proposal for a Regulation of the European Parliament and of the Council on online dispute resolution for consumer disputes (Regulation on consumer ODR), COM(2011) 794/2.
} 
- However, the diversity and uneven geographical and sectoral availability of ADR entities prevent consumers and businesses from fully exploiting their potential.

- In order to develop the full potential of the Single Market as the growth engine for the European economy we need legislative action that ensures that every consumer in the EU can bring a dispute, regardless of the sector in which it has arisen, and regardless of whether it relates to a domestic or a cross-border transaction, to an appropriate ADR entity.

The ADR Directive tackles the three main problem areas:

a. Gaps in the coverage of ADR entities at both sector-specific and geographical level;

b. Lack of awareness and insufficient information preventing consumers and businesses from using ADR entities; and

c. Variable quality of ADR: a significant number of ADR entities are not in line with the core principles laid down by the two Commission Recommendations.

The Communication gives examples of consumer problems that the proposals would solve. It also says that it will introduce the following Flanking Measures:

1. Information campaigns to consumers, workshops for businesses, coordination with national entities;

2. Training and requirements for ADR entities, using the ECC-Net network.

\subsection{The ADR proposal}

As evidence on which to base the proposal, the Commission asserts that a substantial proportion of European consumers encounter problems when buying goods and services in the internal market. In 2010, this was the case for approximately $20 \%$ of European consumers. ${ }^{81}$ The losses incurred by European consumers because of problems with purchased goods or services are estimated at $0.4 \%$ of the EU GDP. The analysis of the current situation identified the following main shortcomings which hinder the effectiveness of ADR: gaps in the coverage, the lack of consumer and business awareness as well as the uneven quality of ADR procedures. ${ }^{82}$

A detailed impact assessment (IA) has been made, analysing a range of policy options for both "ADR coverage, information and quality" and "ODR for cross-border e-commerce transactions". The IA concluded that only a combination of two instruments on ADR and ODR can ensure access to impartial, transparent, effective and fair means to resolve domestic and cross-border consumer disputes out-of-court.

In particular, a Framework Directive is the most appropriate way to ensure full ADR coverage in all Member States, to inform consumers about ADR and to ensure that ADR entities respect specific quality principles. Full ADR coverage will

\footnotetext{
${ }^{81}$ Eurobarometer 342, "Consumer Empowerment", p. 169.

${ }^{82} \mathrm{Cf}$. Study on the use of Alternative Dispute Resolution in the European Union of 16 October 2009, http://ec.europa.eu/consumers/redress_cons/adr_study.pdf, pp. 56-63; 112-115; 120-121.
} 
create the required framework on the basis of which an EU-wide ODR system can effectively deal with disputes relating to cross-border e-commerce transactions.

The proposal applies to procedures for the out-of-court resolution of contractual disputes arising from the sale of goods or provision of services by a trader established in the Union to a consumer resident in the Union. Thus, it would cover accept both, domestic and cross-border disputes. It does not apply to in-house dispute resolution services operated by traders, to direct negotiation, or to judicial attempts at settlement.

The main elements of the proposal are:

1. Ensuring that ADR procedures exist for all consumer disputes.

2. Information on $A D R$ and cooperation. Consumers must be able to quickly identify which ADR entities are competent to deal with their dispute. Traders will have to inform consumers on whether or not they commit to use ADR in relation to complaints lodged against them by a consumer. This obligation will act as an incentive for traders to use ADR more frequently. Member States may delegate responsibility for this task to their ECC-net offices. ADR entities will be encouraged to become members of networks of ADR entities in sector-specific areas. The proposal encourages cooperation between ADR entities and national authorities entrusted with the enforcement of consumer protection legislation.

3. Quality of ADR entities. ADR entities must respect the quality principles of impartiality, transparency, effectiveness and fairness, which are laid down in the two Commission Recommendations, and are given binding effect. The proposal requires that disputes should be resolved within 90 days, and that ADR procedures should remain accessible to all consumers by being free of charge or of moderate costs for consumers.

4. Monitoring. In each Member State, a competent authority will be in charge of monitoring the functioning of ADR entities established on its territory. The competent autorities will publish regular reports on the development and functioning of ADR entities.

The Directive would enter into force in national law 18 months after adoption.

\subsection{The ODR regulation}

Half the existing ADR schemes offer consumers the possibility of submitting their complaint online, very few offer consumers the possibility of conducting the entire procedure online (via online dispute resolution-ODR). ${ }^{83}$

The proposal is closely tied to the development of e-commerce. Objectives are stated of

- Increasing the number of consumers who are willing to buy online from another Member State by $20 \%$ in 2020

\footnotetext{
${ }^{83}$ The 2010 report of the European Consumer Centre's Network indicates that more than half of complaints $(56.3 \%)$ received by the ECC-Net were linked to e-commerce transactions. However, out of the 35.000 cross border complaints received by ECC network in 2010,91\% could not be referred to an ADR scheme in another Member State as no suitable ADR scheme existed (http://ec.europa.eu/consumers/ecc/docs/2010_ annual_report_ecc_en.pdf).
} 
- Increase in the number of businesses that are willing to sell online in other Member States by $10 \%$ in 2020 .

The main elements of the proposal are:

\section{Establishment of the European online dispute resolution system}

The present proposal aims at establishing a European online dispute resolution platform ("ODR platform"). This ODR platform takes the form of an interactive website which offers a single point of entry to consumers and traders who seek to resolve out-of-court a dispute which has arisen from a cross-border e-commerce transaction. The platform can be accessed in all official languages of the EU and its use is free of charge. ADR schemes established in the Member States which have been notified to the Commission in accordance with the "Directive on consumer ADR" will be registered electronically with the ODR platform.

Consumers and traders will be able to submit their complaints through an electronic complaint form which will be available on the platform's website in all official languages of the EU. The platform will check if a complaint can be processed and seek the agreement of the parties to transmit it to the ADR scheme which is competent to deal with the dispute. The competent ADR scheme will seek the resolution of the dispute in accordance with its own rules of procedure within 30 days from the date of receipt of the complaint. The ADR scheme will have to notify to the platform some data in relation to the development of the dispute (date when the complaint was notified to the parties; date when the dispute was resolved; outcome of the dispute).

Under the proposal, a network of online dispute resolution facilitators ("ODR facilitators' network") will be established which will consist of one contact point for online dispute resolution in each Member State. The ODR facilitators' network will provide support to the resolution of disputes submitted via the ODR platform.

2. Information on the EU-wide ODR system

The present proposal requires traders established within the EU that engage in cross-border e-commerce to inform consumers about the ODR platform. This information shall be made easily, directly, prominently and permanently accessible on the traders' websites as well as when the consumer submit a complaint to the trader.

3. Monitoring

An annual activity report will be drawn up on the operation of the platform. The compliance by ADR schemes with the obligations set out in this Regulation will be monitored by the competent authorities to be established in the Member States in accordance with the Directive on consumer ADR. Every three years the Commission will report to the European Parliament and the Council on the application of the Regulation.

4. Data Protection rules

The data entered in the ODR platform by the parties and the ADR schemes will be stored in a database and will be subject to the relevant legislation on data protection.

The financial appropriations for implementing this proposal from 2012 to 2020 are said to amount to EUR 4,586 million in current prices. 


\subsection{Issues arising from the proposals}

The Commission's proposals are simple and bold. They establish a vision of capturing issues between consumers and businesses, solving them and using the information to improve practice and markets. If consumers can be taught to think 'ADR' whenever they encounter a problem, the problem can be sorted out. Many problems will simply revolve around communication of further information, and not be 'disputes'. But disputes can also be resolved quickly and cheaply if consumers think 'ADR' instead of 'courts' or 'lawyers'.

The discussion above has focussed on influencing the behaviour of the private sector. ADR is certainly spreading outside the consumer field. Many European States have extremely effective Ombudsmen for disputes between citizens and the public sector. Such Ombudsmen are effective because they operate directly under Parliamentary authority and mandate, thereby enabling them to behave with great discretion rather than in an authoritarian fashion, and they have built personal reputations of the highest integrity. They do not just resolve individual disputes but (as seen with the private sector TQS principle) can investigate systemic problems and behaviours. The Ombudsmen in the Nordic States, the Netherlands and the United Kingdom have had considerable effect on building a respectful style of relationships between the state and citizens.

Commissioner Reding has also said that use of the proposed DCFR on contract law will engage an ADR pathway for any disputes that arise, ${ }^{84}$ and DG JUSTICE Commission is starting to look at B2B solutions for ADR. Many Member States use ADR also for disputes between the public sector and its contractors and citizens.

However, funding is necessary to construct the necessary ADR infrastructures and operate them. The proposals do not specify where such funding is to come from, thereby keeping national options open. Some Member States pay for some (Netherlands) or all (Sweden) of their ADR systems. But in the current financial climate, governments cannot be expected to find this money. That means that business must be persuaded to fund ADR systems. The research that my colleagues and I have done reveals that business sectors can switch from opposition to active support (and funding) of ADR systems where they see that significant benefits will accrue. Such benefits are usually maintenance of high reputation in competitive markets, or blocking threats of collective litigation.

There is a serious risk that the Commission's ADR proposals will just not work unless businesses across Europe are persuaded to fund them. It is important that a campaign of information is now directed at business. There may be a price: an effective, comprehensive ADR system in exchange for an absence of collective actions.

ADR systems have huge potential to deliver not only effective, cheap and quick solutions to B2C disputes, thereby solving access to justice issues, but also to provide valuable market information that will enhance competition, innovation and safety. ADR systems thereby challenge the traditional role of the courts. Some may be concerned at this. ${ }^{85}$ But others will support the development of a new relationship and

\footnotetext{
${ }^{84}$ Proposal for a Regulation of The European Parliament and of The Council on a Common European Sales Law (European Commission, October 2011) COM(2011) 635, 11.10.2011.

${ }^{85}$ See the critical stance of PH Lindblom [23], 63-93.
} 
function between the courts and private sector ombudsmen. One model would be that courts decide issues of law, and ombudsmen apply settled law to the facts of individual disputes. Hence, there should be a rational transfer of cases between courts and ADR providers. In the $21^{\text {st }}$ century, the civil justice system may change dramatically.

Open Access This article is distributed under the terms of the Creative Commons Attribution Noncommercial License which permits any noncommercial use, distribution, and reproduction in any medium, provided the original author(s) and source are credited.

\section{References}

1. Andenas, M.: National paradigms of civil enforcement: mutual recognition or harmonization in Europe. In: Andenas, M., Hess, B., Oberhammer, P. (eds.) Enforcement Agency Practice in Europe. British Institute of International \& Comparative Law, London (2005)

2. Baldwin, J.: Is there a limit to the expansion of small claims. In: Freeman, M.D.A. (ed.) Current Legal Problems, vol. 56. Oxford University Press, Oxford (2004)

3. Cafaggi, F., Micklitz, H.-W. (eds.): New Frontiers of Consumer Protection. The Interplay Between Private and Public Enforcement. Intersentia, Cambridge (2009)

4. Farhang, S.: The Litigation State. Public Regulation and Private Lawsuits in the U.S. Princeton University Press, Princeton (2010)

5. Haibach, G.: The Commission Proposal for a Regulation establishing a European small claims procedures: an analysis. ERPL (2005)

6. Hodges, C.: A market based competition enforcement policy. In: European Business Law Review, p. $261(2011)$

7. Hodges, C.: European competition enforcement policy: integrating restitution and behaviour control. An integrated enforcement policy, involving public and private enforcement with ADR'. World Compet. 34(3), 383 (2011)

8. Hodges, C.: Europeanisation of civil justice: trends and issues. Civil Justice Q. 28, 96-123 (2006)

9. Hodges, C.: From class actions to collective redress: a revolution in approach to compensation. Civil Justice Q. 28, 41 (2009)

10. Hodges, C.: Multi Party Actions. Oxford University Press, Oxford (2001)

11. Hodges, C.: Nordic compensation schemes for drug injuries. J. Consum. Policy 29, 143-175 (2006)

12. Hodges, C.: Objectives, mechanisms and policy choices in collective enforcement and redress. In: Steele, J., van Boom, W. (eds.) Mass Justice. Edward Elgar, Cheltenham Glos (2011)

13. Hodges, C.: The European approach to justice and redress. Can. Supreme Court Law Rev. (2d) 53, 1 (2001)

14. Hodges, C.: The Reform of Class and Representative Actions in European Legal Systems: A New Framework for Collective Redress in Europe (2008)

15. Hodges, C.: Towards Parameters for EU Civil Justice Systems. In: Vogenauer, S., Hodges, C. (eds.) Civil Justice Systems in Europe: Implications for Choice of Forum and Choice of Contract Law. Hart, Oxford (2011)

16. Hodges, C., Vogenauer, S., Tulibacka, M.: The Funding and Costs of Civil Litigation. A Comparative Perspective. Hart, Oxford (2010)

17. Hodges, C., Benöhr, I., Creutzfeld-Banda, N.: Consumer ADR in Europe. Hart, Oxford (2012)

18. Hodges, C., Peysner, J., Nurse, A.: Litigation Funding: Status and Issues. Centre for Socio-Legal Studies, Oxford (2012)

19. Hondius, E.: Towards a European small claims procedure. In: Thévenoz, N., Reich, L. (eds.) Liber Amicorum Bernd Stauder, Consumer Law. Schulthess, Geneva (2006)

20. Kakouris, C.: Do the Member States possess judicial procedural "autonomy"? CML Rev. 34, 1389 (1997)

21. Kalven, H. Jr., Rosenfield, M.: The contemporary function of the class suit Univ. Chic. Law Rev. 8, 684 (1941)

22. Kortmann, J., Swaak, C.: The EC White Paper on Antitrust Damage Actions: Why the Member States are (Right to be) Less Than Enthusiastic ECLR (2009)

23. Lindblom, P.H.: ADR - the opiate of the legal system? Perspectives on alternative dispute resolution generally and in Sweden Eur. Rev. Priv. Law 1, 63-93 (2008) 
24. Menkel-Meadow, C.J.: Dispute resolution. In: Cane, P., Kritzer, H. (eds.) The Oxford Handbook of Empirical Legal Studies. Oxford University Press, Oxford (2010)

25. Prechal, S.: Community law in National Courts: the lessons from Van Schijndel. CML Rev. 35, 681 (1998)

26. Roberts, S., Palmer, M.: Dispute Processes. ADR and the Primary Forms of Decision-Making. Cambridge University Press, Cambridge (2005)

27. Storskrubb, E.: Civil Procedure and EU Law. A Policy Area Uncovered. Oxford University Press, Oxford (2008)

28. Stuyck, J., et al.: Commission study on alternative means of consumer redress other than redress through ordinary judicial proceedings. Catholic University of Leuven, January 17, 2007, issued April 2007, available at: http://ec.europa.eu/consumers/redress/reports_studies/index_en.htm (2007)

29. Van Gerven, W.: Of rights, remedies and procedures. CML Rev. 37, 50 (2000)

30. Waelbroeck, D., Slater, D., Even-Shoshan, G.: Study on the conditions of claims for damages in case of infringement of EC competition rules. Ashurst (2004)

31. Whelan, C.J.: Small Claims Courts-A Comparative Study. Clarendon, Oxford (1990)

32. Wils, W.P.J.: Should private antitrust enforcement be encouraged in Europe? World Compet. 26(3), 473-488 (2003)

33. Woolf: Lord: Access to Justice: Final Report. HMSO (1996)

34. Woolf: Lord: Access to Justice: Interim Report to the Lord Chancellor on the Civil Justice System in England and Wales. HMSO (1995) 